\section{God in Pain: Inversions of Apocalypse, by Slavoj Žižek and Boris Gunjević}

New York: Seven Stories Press, 20I 2 | 288 pages | ISBN: 978I6098-0369-8 (softback) \$2 I.95

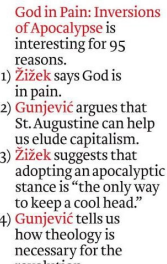

What is to be done when you start repeating yourself? This question kept recurring as I was reading God in Pain. Before I try to answer it, perhaps I should say something about this collection of essays first. It is of the same ilk and seems to have sprung out of the same flurry of "debates" that we find in The Monstrosity of Christ (MIT, 2009) - "debates" because the two protagonists, Žižek and Milbank in this case, spent most of their time talking past each other and simply reiterating old arguments. The present collection has enough of that, at least on Žižek's part, but it is a curious collation (apart from the annoying allusion to Luther's 95 Theses on the cover). At a formal level, Žižek and Gunjević are quite close to one another: both skim across bewildering texts, examples, stories, anecdotes, in a way that seems to avoid close engagement with any one text or thought. Even when ostensibly focused on one object, they run here and there. I suspect this may well have something to do with an educational system in which one covers vast slabs of material, picking up an idea or two and then moving on. But that is only a suspicion.

On the level of content, they are quite disparate. The reader finds it difficult to see where they are actually responding to each other's texts. Instead, we find Gunjević reflecting on the theological core of true revolution, Augustine, the Qur'àn, Radical Orthodoxy, and then the Gospel of Mark (of course, a subversive text). And Žižek offers various pieces on, well, just about everything. But his topics are ostensibly ethics (its suspension), the otiose nature of the structures of religion (which the Christian impulse overturns), the Qur'àn, a suffering God, and then a curious reflection on Derrida and his cat. 
It really is an edited volume, with two authors instead of the usual gaggle. So I take them in turn. Gunjević is the more interesting, but only because he is relatively unknown to English readers. A Lutheran priest and theologian in Croatia, he is clearly enamoured with that strangely parochial and rather conservative venture in the UK known as Radical Orthodoxy. This explains much, for his readings are all rather mainstream. That is, Augustine is read in reply to Hardt and Negri, who do not take the man from Hippo far enough, to offer a theological challenge to the depredations of capitalism. How so? Augustine sees the Roman Empire, for all its flaws, as a divinely appointed means to overcome the various sinful, wayward, and corrupt variations of his own day into one, universal movement. That is, the widespread empire enabled an empire of another sort that would transcend and critique the earthly one. How do you avoid the same temptations reappearing within the movement? Through a dose of good old asceticism, for only in this way can one achieve Beauty, Truth, and Bliss (with the capitals). Forget Augustine's exclusive universal, in which those who did not fit his idea of "catholic" were to be eradicated. Similarly, the reading of Mark's Gospel argues that it is an anti-imperial text, that it deconstructs the messianism of his day, that it was written in a troubled, revolutionary context, and that its call to radical discipleship involves hearing, seeing, watching, and praying. To his credit, Gunjević does cite some of those who have already argued some of thisHorsley, Myers, et al. Not much is to be gained by saying that he is in a familiar groove, within a certain line of New Testament scholarship. I am more interested in the mainstream nature of such a reading. One takes a particular biblical text and argues for a core meaning, here an anti-imperial one. Thus, any reading which runs otherwise distorts the text, bending it to another purpose. All we need do is realise what its proper meaning is, and, since it is after all Sacred Scripture, that is enough. Little, if any, ambivalence here; little recognition of the complicity of such a text with the status quo in its very act of resistance.

To give honour where honour is due, Gunjević does provide some of the best quotes in the book. For example:

Some day when we get around to writing a genealogy of our failures, inadequacies, and disappointments, an important place in such a study will be the books we never read, for whatever reason. Aside from the music we never listened to, the movies we never watched, or the old archives and maps we never explored, 
the books we never read will be one of the indicators of our anachronisms and our flawed humanity. (I 3 I)

Of course, one book that should not be on that list is the Qur'ān, in which the opening line of the first sura that was published (now 96:I) is: "Read in the Name of your Lord Who has created." And that command was given to a man who was illiterate. To his credit, Gunjević does offer a reading of the Qur'ān, one that is a good deal better than Žižek's attempt. Yet even here, the agenda is a curious one, for the purpose is to overcome fundamentalist readings that-he suggests - seek to control the text and fix the meaning, as well as Western imperial readings that sees it as a manual of terror and therefore to be opposed. Perhaps I am missing something, but I cannot help wondering how this approach can sit side by side with his appropriation of Augustine and indeed Radical Orthodoxy.

Now to Žižek: unfortunately there is nothing new here for anyone who has read a reasonable portion of his other works. Only a God who abdicates God-hood can save us; Christianity, unlike Judaism and Islam, faces the reality of sacrifice, that of God; with God everything is permitted (sexual abuse in the churches, imperial terror, libertinage and so on); Christ as the mutilated animal-as-Third; the death of God as the much-needed fiasco; the evils of postmodernism and apocalyptic scenarios; Hegel; Levinas; films; Alain Badiou ... all of this in his perpetual and unrealised search for a real break, a way of resetting the coordinates so that we do not fall back into our old ways. We even find old and much-repeated jokes, such as the one about the man who thinks he is a seed about to be eaten by a chicken (even when "cured" he worries that the chicken does not know he is no longer a seed) or Niels Bohr's horseshoe (it works even if you don't believe in it).

So I come back to the problem of repetition. What do you do when you start repeating yourself a little too often? Is it time to close the books, fold down the computer screen, plant some onions, learn the ukulele or perhaps Italian, and inquire about the retirement village? This is a perpetual problem for anyone who has written as much as Žižek. I am not interested in the unwritten codes of intellectual life, such as the incompatibility between quantity and quality, or the pretence to innovation when it really is business as usual. But I am interested in what happens when the key components of one's thought have developed and when it then becomes a matter of tinkering here and there, reshuffling ideas in ever different combinations, or of simply quoting yourself. This problem is particularly germane to philosophers who 
feel called upon to build systems, with that extraordinary assumption that one can produce a system of the universe while sitting at a desk in a cottage, pencil and paper in hand (or rather, laptop and internet glowing before you). In the end, all you do is reiterate the system, since it can explain everything. I suspect that Negri hit upon an idea in relation to this problem. He once said that the most interesting period for a thinker is when he or she stops writing for a while. Negri experienced this himself for several years, while engaged in activism among the factory workers near Venice. The reason: it signals a problem, an impasse, a need to stop and rethink matters from the ground up. For Žižek that problem is his unfulfilled search for a truly radical break, one that really changes everything. So what would Žižek be like if he did so, if he spent five or even ten years not writing? Is this the real abyss that Žižek fears?

Roland Boer

Renmin University of China 